\title{
AGE-INDEPENDENCE FOR MEDIA PEDAGOGY
}

Rebekka Haubold

ORIGINAL SCIENTIFIC PAPER / DOI: https://doi.org/10.20901/ms.10.20.5 / SUBMITTED: 02.10.2019.

ABSTRACT Age is a static socio-demographic dimension, but is it still a useful category for media pedagogy and media competencies? This article is a theoretical examination of the fixation on age in German media pedagogy research and practice. The thesis of this article, therefore, is that this dominant focus on age should be shifted to neglected contexts and ways to discover them. The key point is to distinguish cases in which it makes sense to focus on age groups in media pedagogical research and practice from those in which it is discriminatory and less important than other factors. Therefore, it analyses historical developments that justified concentration on the subject in German media pedagogy and, thus, the overemphasis on age concepts.

KEYWORDS

INTERGENERATIONAL APPROACH, MEDIA PEDAGOGY, GERMANY, DISCRIMINATION, LITERACY

Author Note

Rebekka Haubold :: Leipzig University, Leipzig, Germany :: rebekka.haubold@uni-leipzig.de 


\section{INTRODUCTION}

Media pedagogy is the field of research and practice which should enhance media competence to participate, and emancipate people in, with and through media (Gapski and Gräßler 2007). German media pedagogy focuses primarily on people in its research and practice (Ganguin et al., 2017: 302). Researchers' and practitioners' question for work is: "What are the people doing with the media?" (Schorb, 2003: 77). Therefore, they define their target groups according to generational lines and the life course (e.g. 'children', 'adolescents', 'adults' or 'seniors') (Hartung et al., 2009; Schäffer, 2003; Rosenstock, 2007). The age is by default interpreted as a meaningful context for media appropriation without proving its relevance. The main assumption of this article is that the dominant focus on age should be shifted to other, neglected, contexts and ways to discover them. The rationale for this article is to analyse the problem of ageism in media pedagogy with the aim to provide alternative approaches for defining target groups. The argumentation is based on the assumption that age has little to do with the ability to develop media competences. Lack of awareness and education among certain demographic groups excludes portions of society from taking advantage of the benefits of recent technological developments. For example, the smartphone, a hybrid of technology and online content, combines the known media and their functions (Hepp, 2005). Daily life fosters its obligatory usage (Givskov and Deuze, 2018: 400) because non-smartphone-users are expelled from messenger-groups with family or peers (Rosales and Blanche-Tarragó, 2018). Digital exclusion also occurs with issues related to current schedules and low-priced tickets for public transportation, from administration (Sanchez-Valle et al., 2018) or their online bank accounts (bitkom, 2018).

The article discusses the theoretical impacts of this emphasis on different usages of age concepts by considering arguments for age as an anchor category, as well as the limitations of it. Further, it shows, by giving examples from German media pedagogical work, how age-categories lead to discrimination against older adults. By illustrating the disadvantages, the article encourages researchers and practitioners in the field of media pedagogy to reconsider the use of categories which do not specify the subjects of research: people and media. Referring to the genealogy of German media pedagogy, the article seeks reasons for focusing on age groups in order to find a way to avoid this phenomenon.

\section{ADVANTAGES AND DISADVANTAGES OF FOCUSING ON TARGET GROUPS OF AGE}

From a media and communication science perspective, media pedagogy is a subdiscipline of sociology where borrowing concepts as the socio-demographic can be appropriate. The basic assumption here is that: "Chronological age, a property of individuals, may stand as a proxy for biological maturation, psychological development, membership in larger social categories (e.g., cohort), or life stage or phase" (Settersten and 
Mayer, 1997: 234). Nevertheless, we need to specify it for our research and practice object, i.e., the media, considering that

we know that chronological age itself is an "empty" variable we rarely assume that it is age itself that causes a behavior; instead, it is whatever age presumably indexes that is thought to be important (...) we must ask ourselves why age is being measured and how it will be used. (Settersten and Mayer, 1997: 238).

\section{AGE AS A FOUNDATION OF EQUALITY}

In media pedagogical research and practice, age is used as an indicator of various complex conditions, yet with some limitations.

\section{(1) Orientation on the Curriculum and Socialization}

Media educators use age as an index, when they take socially defined positions into consideration, such as kindergarten, pupils, young people or retirees. These concepts refer to age as an anchor category, which is useful when planning or researching media appropriation or media competences within a curriculum. In educational systems, such as the school system, people can be classified by age, because of the fact that the individual's current career step mirrors his/her socialization process. Even in this case, there are differences between different school systems or regions, like comparing lowerclass schools with private ones. With the end of schooling, people's career steps differ (Haubold and Ganguin, 2017) and age is not an indicator of the connection between working life and media competences.

Diversity within generations of adults is high in terms of career patterns (Bergström, 2017; Christensen, 2017; Givskov and Deuze, 2018; Haubold and Ganguin, 2017; Stone et al., 2016; Doh, 2011). Therefore, age is not relevant in informal or non-formal mediapedagogical research and practice or personal media use in leisure time or daily routines. Therefore, age could be one variable for adults.

\section{(2) Orientation on Different Steps of Development}

Similar interests of the target group can also be structured by using age as an anchor category through specific development issues (Faltenmaier et al., 2013). Focusing on age in this case means emphasizing the conditions of a target group while neglecting their interests, skills and abilities. This connection is valuable in stages of life when usage-skills and abilities have yet to be developed.

According to Beate Sodian (2008), the psychological basis for seeing, listening, or conscious touching are developed around the age of twelve. Furthermore, the ability to understand and abstract, the ability of hypothetical thinking and reflection should be reached by this age (Horn et al., 2016; Krampen, 2008; Oerter and Dreher, 2008). People thus have all physical and psychological skills needed for competent media use when they are around twelve years old, and they are fully developed for establishing media 
competences. These abilities do not decrease with age. The skills and abilities which are needed for media-usage do not distinguish adults from older people or teenagers (Bergström, 2017; Christensen, 2017; Haubold and Ganguin, 2017).

\section{(3) Discovering the Backgrounds of the Indicator Age}

An alternative to using the empty variable of age as a category is to investigate the content of media competence and medium-specific interests of the subjects (Haubold and Ganguin, 2017). Both can be age-independent. Age-related concepts were imported to media pedagogical research, such as biography-research, generational approaches, or research about life span and life-caesuras (Hartung et al., 2009; Schäffer, 2003; Beck et al., 2016; Rosenstock, 2007). These approaches try to overcome discrimination by investigating the differences which result from ageism (Baetge and Harnisch, 2013). Therefore, it is appropriate to use phases of life (Beck et al., 2016; Kruse, 2011; Doh, 2011) as a variable instead of chronological age or age as an anchor category. Nevertheless, age still plays a role as a guideline in these approaches because they are structured chronologically.

\section{DISCRIMINATION AND AGEISM: MEDIA PEDAGOGY AS A PRIVILEGE OF YOUNG PEOPLE}

Targeting by age groups results in age-discrimination, which can be found in German media pedagogical research and practice. Ageism refers to the "marginalization and discrimination" (Krekula et al., 2018: 33) of groups of people according to their age. The term was formulated to stress the discrimination against older people (Ayalon and TeschRömer, 2018: 2). The consequences of this are symbolic, cultural, discursive and ideological and are seen in social practices (interactions), social structures, organizations, and institutions (Berger, 2018: 1). They affect different living conditions, mutual recognition, educational possibilities, as well as material and immaterial resources (ibid.). All these aspects can be identified in German media pedagogical research and practice.

\section{(1) Effects in Organizations and Institutions: Deficient Research}

German media pedagogical professions are mostly connected to educational research, which is closely linked to school or teacher training (GMK, 2018a). Twelve media pedagogical professions are directly linked to teachers' training for primary and secondary school. Further, nine degree-courses are highly specialized in children and media; one of them researches early childhood. In contrast, there is no media degree programme which researches seniors, and only three media pedagogical professions relate directly to adult education (GMK, 2018a). It should not be the aim to demand a profession like this - for reasons which are explained later - but this illustrates disparity.

\footnotetext{
${ }^{1}$ Nevertheless, ageism is a problem for younger people as well (ibid.). Following the definition of Butler, ageism is a phenomenon around three aspects: "(1). Prejudice against older adults, old age, and aging (i.e.,attitudes towards older adults), (2). Discrimination against older adults (i.e., behavioral acts targeting older adults), and (3). Institutional norms and strategies supporting stereotypes and reducing the opportunities of older adults." (Ayalon and Tesch-Römer, 2018: 12, as quoted by authors).

To speak about the first aspect, empirical research is needed, that survey if and how ageism comes upon German media pedagogies. This article concentrates on the second and especially on the third dimension.
} 
The essential media pedagogical research institute, the JFF (Institute for Media Pedagogy in Research and Practice), concentrates on children and adolescents (JFF, 2018). Likewise, the media pedagogical research association South-West (the mpfs) collects data about the media usage of children and young people (mpfs 2018). In 2012, the JFF started to stress the early childhood by introducing the miniKIM research panel, which focusses on two to five year old children. Since 2016, they have expanded their research on children's families, but the main focus is still on children (mpfs, 2018).

Even when media pedagogy takes seniors into account, the main focus lies on the description of their deficiencies in comparison to ordinary users. "Life's caesuras" (Kruse, 2011: 254; Doh, 2011: 20, 73) of older people focus on gone things. The orientation on biological physical and psychological changes (Simon et al., 1999: 29) ask for tasks to cope. Furthermore, concepts of generational media usage try to explain why older people use media differently (Thalhammer, 2017; Hepp et al., 2014, 2015), which fosters and reinforces stereotypes (Schorb, 2017: 256).

\section{(2) Effects in Educational Opportunities: Young People vs. the Leftovers}

The media authorities in Germany, the major actors in informal media education, define 'children and young people' (die medienanstalten, 2018a) as their target groups for enhancing media competencies. Three out of the fourteen media authorities list 'adults', one 'seniors' and only the media authority of the smallest federal state, Saarland, names 'all' as its target group (die medienanstalten, 2018b). The German Professional Association for Media Education (GMK) focuses the informal media education on young people (GMK, 2018b). The most important media pedagogical German award for best practice the Dieter Baacke Preis groups projects with older people together with those involving disabled people ${ }^{2}$ with the purpose of 'exchange between generations' (von Gross et al., 2018)3 which means that young people are required.

This stereotyped image of pedagogical work implies that intergenerational practice means that young people teach older. Projects are built around children and their grandparents (die medienanstalten, 2016: 120). The media authorities have been funding projects where 'intergenerational' means that seniors get an insight into new media from children or young people (die medienanstalten, 2018b). If older people are involved or addressed in practice projects, their strengths are reduced to 'life experience' (Mayer, 2009: 115, 122), which is discriminatory and follows false assumptions. Young people are not necessarily in touch with the media or informed about all their functions (Initiative D21 e.V., 2019: 38). Secondly, this describes only technical competence while reflexive competencies in particular are rarely addressed. Thirdly, technical competence is unrelated to teaching skills. Moreover, new media are built upon functions from the existing media and, thus, are not entirely new, so they are familiar to experienced users.

\footnotetext{
${ }^{2}$ While on the subject, it is worth noting that this is discriminative against disabled people as well. In point of fact, it seems as if their disabilities were not taken seriously.

3 The translation of category 4 of the Dieter-Baacke-Preis: “intergenerational/integrative projects (e.g. media pedagogical cooperation, exchange between generations, family-oriented media work, media pedagogical projects in the context of inclusion or integration of children and young people with disabilities)" (GMK, 2018c).
} 


\section{(3) Social Interaction: Mutual Recognition as Symbolic and Positive Discrimination}

Discrimination is reflected by the use of derogatory terms like 'Silversurfers' (Röser, 2017), 'Silvergamers' (Kohring and Heinz, 2012) or 'Senior-Courses' (die medienanstalten, 2018b). The term 'Silversurfer', for example, refers to physical ageing because it creates an image of elderly media users, who supposedly act differently from other groups. It is a classical difference construction (Scherr, 2017: 44) and additional linguistic discrimination (Schorb, 2009: 320). It was not possible to find a homogenous media usage of the olderaged generation (Loos, 2012; Doh, 2011). Instead, there are different media generations, where older people are subordinated (Hepp et al., 2017: 81; Beck et al., 2016; Hepp et al., 2015).

An effect of considering people as special media users is that parallel media-worlds are created. Middle-aged and senior users are interesting for economic reasons (Schorb, 2009: 320). Meanwhile, the Federal Ministry claims that people are "never too old for the Internet" (BMFSFJ, 2018) and implicates topics, which are just for retired persons. There has been some research about digital immigrants or older people's abstinence from new media content and practical ways to integrate them (e.g., Hartung et al., 2012-2019). Courses about smartphone-use for mature people have emerged (Kübler, 2019), and research has begun to address the leftovers (BMBF, 2018; BMFSFJ, 2018).

Dealing with these stereotypes is hard (Klein, 2017; Baetge and Harnisch, 2013) because it leads to self-stereotyping (Rebelo, 2018), which leads to problems in daily life (Thomas and Thomas, [1928] 1970). Discrimination occurs because of established stereotypes, which are also reproduced in media pedagogical practice.

\section{HISTORICAL BACKGROUND: REASONS FOR THE DOMINANT FOCUS ON AGE}

An explanation for why German media pedagogy addresses target age groups and is biased in favour of young people can be found in its history.

\section{From Protecting to Privileging Minors}

One of the largest fields of work in media education in Germany is protection of minors. In cases of media protection, age as a socio-demographic factor still plays a dominant role in research and practice. In the beginning, the groups who were media-protected were not addressed in relation to age, but in terms of their reading skills (Stöber, 2003: 140). Subsequently, women and non-adults were once defined as those who were protected from the content of "trash and dirt literature" (Barth, 2002: 82; Jäger, 1988: 173). Whereas gender has ceased to matter in targeting media protection, the youth and children are still protected from harmful media content by German law (BMFSFJ, 2014). German youth media protection still distinguishes children aged zero to six; twelve; sixteen and eighteen. (JuSchG \& JMStV, 2015). This dominant focus on young people makes sense in terms of 
orientation on development psychology. Otherwise, it is questionable, if the categories of decision making that youth media protection is using - such as fear, violence, sexuality, or extremism (KJM, 2019) - are completely age-independent and could be directly classified (as the Pan European Game Information (PEGI) already does). In this case, people could decide on their own (or parents for their children) if they are old enough for the content. Such a method already works in practice because there is no age limit for books.

After the media pedagogical phase of protection, media pedagogy focused on education and especially on children's and youth's education (Hüther and Podehl, 2005). Educational technologists, for instance, produced media and media content for schools (Hüther and Podehl, 2005). Whereas German media pedagogy aimed to educate the entire population after World War II to limit the effects of propaganda, recent research has concentrated on young people's education, thus focusing on their work at school (Süss et al., 2013). Media pedagogues have established target-group-friendly content and methods for young people, such as school films or a children's channel (KiKA) (Hüther and Podehl, 2005). The media authorities have been founded. Also, researchers focus on the target groups of young people to learn more about their daily lives, their particular problems and requirements (as the research institutes JFF and mpfs still do today).

In later years, media educational researchers and practitioners opened the field of labour. Since the rise of the Internet, media pedagogy has dealt with careers (Hüther, 2005). 'Media pedagogy for adults' means 'media pedagogy for vocational education' (Helbig and Hofhues, 2018). Retired people's human resources offered focusing on the target group of older adults with the appeal to life-long learning. An economic rather than pedagogical, perspective has been adopted, which gives rise to a new problem: The oldest are excluded from access to media pedagogy because they are not part of the labour market (Schorb, 2009: 319).

\section{FOCUSING AGE THROUGH MISUNDERSTOOD DIDACTIC DEFINITIONS}

Current discrimination against adult media users stands in opposition to the postulation of an age-independent approach of pedagogy and especially of media competence's aims (Schorb, 2017: 256). The limited target groups of media pedagogical work and research were not intentioned. On the contrary, Comenius - as one of the cornerstones of German media education - demanded education for everyone (Schaller, 1995). Even though Comenius tried to prepare content for a younger generation, he intended to do so for all, particularly for those who are disadvantaged, who are unprivileged (Schaller, 1995).

With the development of media competence concepts, the focus shifted to the consideration of age. The models contain 'reflexive' (Baacke, 1996; Schorb, 1997; Moser, 2010; Groeben, 2002), 'cognitive' (Schorb, 1997; Aufenanger, 1997; Kübler, 1996; Tulodziecki, 1997) or 'affective' (Aufenanger, 1997) dimensions. They are theoretically described as being age-independent, but in research and practice, they define groups based on age. To 
differentiate target groups by aspects other than stages of development shifts the anchor category to age groups. Dieter Baacke (1980a; Baacke and Vollbrecht, 2003) describe media competences as didactics to deal with media. He differentiates the categories of young people from $0-5,6-12$, and $13-18$ years, yet his idea of media competence is ageindependent (Baacke, 1979; 1980b; 2004; 2018). Nevertheless, these categories are used as target groups and in a way that excludes adults.

Marc Prensky (2001: 6) has a similar idea as he formulates the 'digital natives' and 'digital immigrants' as different types of media appropriators, who need new ways to plan the didactics with new "methodologies for all subjects, at all levels". Unfortunately, it led to discrimination, when digital natives were characterized as young and digital immigrants as mature adults (Loos, 2012) even though new media are new for everyone. Also, everyone needs new ways to appropriate them. For this reason, it is necessary to overcome the agebased target groups and re-establish an age-independent media pedagogy.

\section{CONCLUSION: OVERCOMING THE DOMINANT AGE-FOCUS}

This article offers impulses for reconsidering the dominant focus on age (when discussing target groups in media pedagogy). The proxy of age reaches its limits by referring to adults and older people. The concepts reach their limits when media pedagogy is dedicated to people from the age of twelve and non-formal and informal education. Therefore, the proxy age should not be overrated. Focusing on age leads to neglecting other attributes that are probably relevant, such as biographical caesuras, developmental or generational issues.

The article illustrates that ageism is a problem within German media pedagogy in its organisational and institutional aspects. Research and practice focus on the categories of age, particularly young people. One consequence of this is that the elderly or older people is used as a residual category in which to collect a kind of leftovers respectively young people, for whom the media pedagogical projects are conceptualized. It ends up in fewer educational possibilities for leftovers. In this case, middle-age groups of 'adults' are discriminated as well. Older-aged adults face symbolic discrimination by being targeted through the use of deficient and difference constructions. By trying to address the leftovers, an overemphasis on the group of non-minors leads to positive discrimination (as Rothermund and Temming (2010) describe as a problem for democracy). All these effects of ageism have an impact on material and immaterial resources, thus excluding older people not only from media education but also from daily life practices.

To discover the reasons for the normative depiction of age and frequent discrimination that adults and seniors face when dealing with media, the article summarises historical developments of media pedagogy in Germany. Media educators started with the ageindependent idea of including the unprivileged and protecting the youth. This evolved into a form of privileged treatment in which those who are not children or adolescents 
are neglected. Both Comenius and media pedagogues who developed models for media competence (by following the Habermasian perspectives of Enlightenment about a selfdetermined subject (such as Baacke (1996), Schorb (1997) or Gapski (2001)), implemented media pedagogy for everyone, especially for unprivileged people and minorities. The didactic implementation where developmental psychological stages are decisive led to the misconception that age differences are relevant to media appropriation. Subsequent analysis of the roles that media play in the labour market led to a focus on employees who are in preparation for, or within working life, while those who do not participate remain as leftovers.

Stressing age as an anchor category causes ageism and discrimination, which disadvantages the supposed group of older people even though they are not different from others in their media appropriation, which stands in contrast to an age-independent aim of media pedagogy. The aim should be to re-establish media pedagogy for everyone again.

One of the problems of emphasising age lies in the orientation on psychological development, which uses age as an anchor category. Through creating didactic ways to inform media competence, those concepts were overtaken. This explains the focus on the subject within the German media competence approaches. From an idealistic point of view, the main concepts argue top-down and describe how a person should be to become a competent individual (Schiefner-Rohs, 2013). The subject's predispositions, especially the development stages, are based on age.

A way to solve this subject-centrist perspective is to combine it with the AngloAmerican media-literacy ideas, where the emphasis lies more on the media (see Table 1.). Contrary to the theoretical German media competence, the media literacy tradition lies in pragmatism (Dewey, 1997). Following the aim of alphabetization - as the word literacy illustrates - it is an empirical approach (Ganguin et al., 2017). With the aim to decode information (Swertz and Fessler, 2010), the media are described as technical devices and mediators of content. The question is: What do the media want to be done by the subject? To understand the media and become literate, it is necessary to know and see through their technical characters whereby the subject is described as a user: What allows the media to be done by the person? The focus lies on functional skills and abilities, which a person needs to act with the media (Aufderheide and Firestone, 1993). Therefore, the perspective completes the German one that takes these skills and abilities for granted (Baacke, 1996). Moreover, both most central media literacy models standardize the steps of decoding (Livingstone, 2004; Potter, 2004), and target media-specifics. Consequently, they describe them independently of the subject (i.e. they are age-independent). 
Table 1. General Comparison of German Media Competence and Anglo-American Media Literacy Perspectives (cf. Gemkow and Haubold, 2016).

\begin{tabular}{|c|c|c|}
\hline Media Competence & $\begin{array}{l}\text { Category } \\
\text { of Comparison }\end{array}$ & Media Literacy \\
\hline $\begin{array}{l}\text { Enlightenment } \\
\text { (Theoretical) }\end{array}$ & History & $\begin{array}{l}\text { Literacy/Alphabetization } \\
\text { (Pragmatic) }\end{array}$ \\
\hline $\begin{array}{l}\text { Idealistic Dimensions for a Subject } \\
\text { (Pedagogical Ideal) }\end{array}$ & Focus on & $\begin{array}{l}\text { Pragmatic Steps of Acting with Media } \\
\text { (Explicit Usage) }\end{array}$ \\
\hline $\begin{array}{l}\text { Deductive, Normative } \\
\text { (Top Down) }\end{array}$ & Concept & $\begin{array}{l}\text { Deductive, Normative } \\
\text { (Bottom Up) }\end{array}$ \\
\hline Participating/Emancipated Subject & Aim & Decoding Media Messages \\
\hline $\begin{array}{l}\text { Creator of Media / Self-Determined } \\
\text { Part of Society }\end{array}$ & Subject & User of Media \\
\hline Cultural Objects & Media & Technical Devices with Specific Characters \\
\hline
\end{tabular}

Through this polarisation, a wide spectrum of how media pedagogical work can be situated is demonstrated (see Table 1.). Focusing on the subject is only one possibility. Therefore,

$>$ Instead of stressing the subject's characteristics, the Anglo-American perspective gives various connection options to emphasize a wide range to describe media competence/literacy.

$>$ There is a lack of empirical exploration on the German side.

$>$ The idealistic view needs a pragmatic counterpart, inasmuch that the situational aims of the person do not step back behind theoretical ideals, which would connect the concept of media education with the one of media competence.

In an interactional perspective (Süss et al., 2010: 60; Schorb, 1995: 46), neither centres on the subject nor the medium. It also solves the problem that each dimension is limited in its relation to the media pedagogical practice, where mediatization (Krotz, 2001) connects these concepts. Interaction, thus, defines what is relevant in the situation of the media appropriation process. Depending on this, age could be a context but is no context per se.

Therefore, one way for age-independent media pedagogy could be to reclassify people regarding their media appropriation along both of the questions, instead of focusing on only one, thus developing subject-media-specific categories. Instead of borrowing contexts like age from socio-demographics, it is important to prove which contexts are essential for and in the single situation of interaction, which contexts are necessarily relevant. 
The article invites media pedagogical practitioners and researchers to prove the relevance of age by defining target groups and to further investigate more research subject-specific contexts. These arguments simultaneously draw attention to a significant desideratum in an age-independent - and for this less discriminatory - media pedagogical research and practice.

Instead of borrowing concepts from other social sciences or using old fashioned categories or finding contexts of media appropriation on purpose or by accident, it is necessary to investigate and use media- and subject-specific contexts, too. The recommendations are:

>not to fall back on the common age-dependent target groups, when searching for equalities between them,

$>$ to be sensitive to discrimination, especially to ageism and,

$>$ to take other contexts into account.

The foregoing refers to both subjects of research: people and media. The recommendations are intended to establish age-independent media pedagogical research and practice.

In summary, the article provides the field of media pedagogy with a novel approach through combining perspectives and media scientific traditions. The table focuses on a wider spectrum of contexts of adult media appropriation and, thus, provides multiperspective approaches, which could shift the problem of ageism in media pedagogy.

\section{References}

>Aufderheide, Patricia and Firestone, Charles (1993) Media literacy: A Report of the National Leadership Conference on Media Literacy. Washington, D.C.: Communications and Society Program, the Aspen Institute.

>Aufenanger, Stefan (1997) Medienpädagogik und Medienkompetenz - Eine Bestandsaufnahme (Media Pedagogy and Media Competence - An Inventory), pp. 15-22 in Enquete Kommission (ed.) Medienkompetenz im Informationszeitalter (Media Competence in the Age of Information). Vol. 4 ("Zukunft der Medien in Wirtschaft und GesellschaftundDeutschlands Weg in die Informationsgesellschaft"). Bonn: Enquete-Kommission: Zukunft der Medien.

$>$ Ayalon, Liat and Tesch-Römer, Clemens (2018) Introduction to the Section: Ageism - Concept and Origins, pp. 1-10 in Ayalon, Liat and Tesch-Römer, Clemens (eds) Contemporary Perspectives on Ageism, International Perspectives on Aging, vol. 19. Springer: Cham. https://doi.org/10.1007/978-3319-73820-8_1.

>Baacke, Dieter (2018) Die 0- bis 5-Jährigen: Einführung in die Probleme der frühen Kindheit (The 0- till 5-Years-Olds: Introduction in the Problems of Early Childhood). Weinheim, Basel: Beltz Juventa.

>Baacke, Dieter (2004) Die 6- bis 12-Jährigen: Einführung in die Probleme des Kindesalters (The 6- till 12-Years-Olds: Introduction in the Problems of Childhood). (6th Ed.) Weinheim: Beltz.

>Baacke, Dieter (1996) Medienkompetenz - Begrifflichkeit und sozialer Wandel (Media Competence - Terms and Social Change), pp. 112-124 in Rein, Antje von (ed.) Medienkompetenz als Schlüsselbegriff (Media Competence as Keyterm). Bad Heilbrunn: Klinkhardt.

>Baacke, Dieter (1980a) Kommunikation und Kompetenz. Grundlegung einer Didaktik der Kommunikation und ihrer Medien (Communication and Competence. Basics of a Didactic of Communication and its Media). (3rd Ed.) München: Juventa. 
>Baacke, Dieter (1980b) Die 0- bis 5-Jährigen: Einführung in die Probleme der frühen Kindheit (The 0- till 5-Years-Olds: Introduction in the Problems of Early Childhood). München: Urban und Schwarzenberg. >Baacke, Dieter (1979) Die 13 bis 18 jährigen (The 13 till 18 Years-Olds). (2nd Ed.) München: Urban und Schwarzenberg.

>Baacke, Dieter and Vollbrecht, Ralf (2003) Die 13- bis 18-Jährigen: Einführung in die Probleme des Jugendalters (The 13- till 18-Years-Olds: Introduction in the Problems of Adolesence). (8th Ed). Weinheim Basel: Beltz.

>Baetge, Caroline and Harnisch, Tobia (2013) Anerkennung und Alter: Die Rolle von Biografie und Medien (Acknowledgment and Age: The Role of Biography and Media). Medienwelten - Zeitschrift für Medienpädagogik (2): 1-237. http://doi.org/10.13141/zfm.2013-2.53.54.

>Barth, Susanne (2002) Mädchenlektüren: Lesediskurse im 18. und 19. Jahrhundert (Girl-Readings: Reading-Discourses in 18th and 19th Century). Frankfurt/Main: Campus-Verl.

>Beck, Klaus; Büser, Till and Schubert, Christiane (2016) Mediengenerationen: Biografische und kollektivbiografische Muster des Medienhandelns (Media-Generations: Biographical and CollectiveBiographical Patterns of Media-Action). Konstanz, München: UVK Verl.-Ges.

>Berger, Christian (2018) Diskriminierung (Discrimination). Gender Glossar / Gender Glossary (6 paragraphs). https://gender-glossar.de/glossar/item/85 (28/04/2019).

$>$ Bergström, Annika (2017) Digital Equality and the Uptake of Digital Applications among Seniors of Different Age. Nordicom Review, 38 (s1): 79-91. https://doi.org/10.1515/nor-2017-0398.

>bitkom Research (2018) Digital Banking. https://www.bitkom.org/sites/default/files/file/import/ Bitkom-Praesentation-Digital-Banking-07-05-2018-final.pdf (28/04/2019).

$>$ BMBF (2018) Technik zum Menschen bringen. Forschungsprogramm zur Mensch-Technik-Interaktion (Bringing the Technology to the People. Research Programm for an Human-Technology-Interaction). Bundesministerium für Bildung und Forschung (Federal Ministry of Education and Research) April 2018. https://www.bmbf.de/upload_filestore/pub/Technik_zum_Menschen_bringen_ Forschungsprogramm.pdf Retrieved from: https://www.bmbf.de/de/technik-zum-menschenbringen-149.html (02/09/2019).

>BMFSFJ (2014) Jugendschutzgesetz und Jugendmedienschutz-Staatsvertrag der Länder(Youth-MediaProtection-Law and the Federal States' Youth-Media-Protection-Interstate-Treaty). Bundesministerinfür Familie, Senioren, Frauen und Jugend (Federal Ministry for Family Affairs, Senior Citizens, Women and Youth) (7th Ed.). https://www.bmfsfi.de/blob/94082/3711cb37be8733a15a3c605cf326ee63/ jugendschutzgesetz-jugendmedienschutz-staatsvertrag-data.pdf (20/11/2018).

>BMFSFJ (2018) Nie zu alt fürs Internet (Never Too Old for the Internet). Bundesministerium für Familie, Senioren, Frauen und Jugend \& Verbraucherzentrale Rheinland-Pfalz (Federal Ministry for Family Affairs, Senior Citizens, Women and Youth in cooperation with Consumer Advice Centre Rhineland-Palatinate) (8th ed.). Frankfurt am Main: Zarbock. https://www.bmfsfj.de/blob/94430/ d308f95a0282d82ae9e6da557a43c855/nie-zu-alt-fuers-internet-data.pdf (20/11/2018). $>$ Christensen, Christa L. (2017) Healthy Ageing and Mediated Health Expertise. Nordicom Review 38 (s1): 9-23. https://doi.org/10.1515/nor-2017-0403.

$>$ Dewey, John (1997) Experience and education. (1. Ed.). The Kappa Delta Pi Lecture Series. New York: Simon \& Schuster.

$>$ die medienanstalten (2016) Medienkompetenzbericht der Medienanstalten (Media-CompetenceReport of the Media Regulatory Authorities). Berlin: VISTAS Verlag. https://www.lfk.de/fileadmin/ media/die_Ifk/Medienkompetenzbericht_der_Medienanstalten_2016.pdf (20/11/2018). > die medienanstalten (2018a) Die Medienanstalten. Medienkompetenz (The Media Authorities. Media Competence). https://www.die-medienanstalten.de/themen/medienkompetenz/ English Version: https://www.die-medienanstalten.de/en/about-the-media-authorities/ (20/11/2018). > die medienanstalten. (2018b) Verzeichnis Medienkompetenzprojekte - 03-2018 (List of MediaCompetence-Projects - 03-2018). https://www.die-medienanstalten.de/publikationen/weitereveroeffentlichungen/artikel/news/medienkompetenzbericht/ (or directly: https://www. die-medienanstalten.de/fileadmin/user_upload/die_medienanstalten/Service/Downloads/ Verzeichnis_Medienkompetenzprojekte.pdf) (20/11/2018). 
>Doh, Michael (2011) Heterogenität der Mediennutzung im Alter: Theoretische Konzepte und empirische Befunde (Heterogeneity of the Media-Usage in Old Age: Theoretical Concepts and Empirical Findings). Gesellschaft - Altern - Medien (Society - Aging - Media): Vol. 2. München: kopaed. $>$ Faltenmaier, Toni; Mayring, Philipp; Saup, Winfried and Strehmel, Petra (2013) Entwicklungspsychologie des Erwachsenenalters (Development Psychology of Adulthood. 3rd Ed. Stuttgart: Kohlhammer.

$>$ Ganguin, Sonja; Gemkow, Johannes and Haubold, Rebekka (2017) Information Overload as a Challenge and Changing Point for Educational Media Literacies, pp. 302-328 in Marques, Rui P. and Batista, Joao C. (eds) Information and communication overload in the digital age. Hershey, PA: IGI Global. https://doi.org/10.4018/978-1-5225-2061-0.ch013.

$>$ Gapski, Harald (2001) Medienkompetenz. Eine Bestandsaufnahme und Vorüberlegungen zu einem systemtheoretischen Rahmenkonzept (Media Competence. An Inventory and Preliminary Considerations for a System-Theoretical Framework). Wiesbaden: Westdeutscher Verlag

$>$ Gemkow, Johannes and Haubold, Rebekka (2016) Transnational Approach on Media Literacy and the German Concept of Media Competence. Poster presented at the 6th European Communication Conference (ECC): Mediated (Dis)Continuities: Contesting Pasts, Presents and Futures. 09.12.11.2016 in Prague.

$>$ Givskov, Cecilie and Deuze, Mark (2018) Researching new media and social diversity in later life. New Media \& Society 20 (1): 399-412. https://doi.org/10.1177/1461444816663949.

$>$ GMK (2018a) Studiengänge für Medienpädagogik und Erziehungswissenschaft (Degree Courses for Media Pedagogy and Educational Science) (September 2018). GMK and DGfE Sektion Medienpädagogik (eds). https://www.gmk-net.de/wp-content/uploads/2018/09/studiengaenge_ medienpaedagogik_medienwissenschaften_erziehungswissenschaften.pdf (20/11/2018).

>GMK (2018b) About GMK. Gesellschaft für Medienpädagogik und Kommunikationskultur in der BundesrepublikDeutschland e.V. (Professional Association for Media Education, Media Literacy and Communication Culture; registered, non-profit organisation). https://www.gmk-net.de/about-gmk/ (20/11/2018).

$>$ GMK (2018c) Über den Preis: Kategorien. (About the Price: Categories) https://dieter-baacke-preis. de/ueber-den-preis/kategorien/ (12/12/2019).

$>$ Gapski, Harald and Gräßler, Lars (2007) Medienkompetenz im Web 2.0 - Lebensqualität als Zielperspektive (Media Competence in Web 2.0 - Quality of Life as Target), pp. 11-34 in Gräßer, Lars and Pohlschmidt, Monika (eds) Praxis Web 2.0. Potenziale für die Entwicklung von Medienkompetenz (Praxis Web 2.0. Potentials for the Development of Media Competence). (Schriftenreihe Medienkompetenz des Landes Nordrhein-Westfalen). Düsseldorf: kopaed.

$>$ Groeben, Norbert (2002) Dimensionen der Medienkompetenz. Deskriptive und normative Aspekte (Dimensions of Media Competence. Descriptive and Normative Aspects), pp. 160-167 in Groeben, Norbert and Hurrelmann, Bettina (eds) Medienkompetenz - Voraussetzungen, Dimensionen, Funktionen (Media Competence - Conditions, Dimensions, Functions). Weinheim: Juventa. $>$ von Gross, Friederike, Meister, Dorothee and Eder, Sabine (2018) Dieter Baacke Preis. Die bundesweite Auszeichnung für medienpädagogische Projekte. Informationen (Dieter Baacke Price. The Nationwide Award for Media-Pedagogical Projects. Information). Retrieved from: https://www.dieterbaacke-preis.de/dieter-baacke-preis/info/ (20.11.2018).

$>$ Hartung, Anja; Hoffmann, Dagmar; Kübler, Hans-Dieter; Schorb, Bernd and Schwender, Clemens (eds) 2012-2019. Medien und Altern. Zeitschrift für Forschung und Praxis (Media and Aging. Journal for Research and Practice).

>Hartung, Anja; Schorb, Bernd; Küllertz, Daniela and Reißmann, Wolfgang (eds) (2009) TLMSchriftenreihe Vol. 20: Alter(n) und Medien:Theoretische und empirische Annäherungen an ein Forschungs- und Praxisfeld (TLM-Publication Series Vol. 20: Age and Media: Theoretical and Empirical Approaches to a Research-and Practice-Field). Berlin: Vistas. 
>Haubold, Rebekka and Ganguin, Sonja (2017) The Elderly's Media Appropriation as Variable for Target Groups. Networking Knowledge: Journal of the MeCCSA Postgraduate Network, 10 (1): 27-43. $>$ Helbig, Christian and Hofhues, Sandra (2018) Leitideen in der medienpädagogischen Erwachsenenbildung: Ein analytischer Blick (Guidelines in Media Pedagogical Adult Education: An Analytical View). MedienPädagogik 30: 1-17. https://doi.org/10.21240/mpaed/30/2018.02.26.X. $>$ Hepp, Andreas (2005) Kommunikative Aneignung (Communicative Appropriation), pp. 67-79 in Mikos, Lothar and Wegener, Claudia (eds) Qualitative Medienforschung (Qualitative Media Research). Konstanz: UVK Verl.-Ges.

>Hepp, Andreas; Berg Matthias and Roitsch, Cindy (2017) Mediengeneration als Prozess: Zur Mediatisierung der Vergemeinschaftungshorizonte von jüngeren, mittelalten und älteren Menschen (Media-Generation as Process: To the Mediatization of Communitization-Horizons of Younger, Middle-Aged and Older Age People), pp. 81-111 in Krotz, Friedrich; Despotović, Cathrin and Kruse, Merle-Marie (eds) Mediatisierung als Metaprozess:Transformationen, Formen der Entwicklung und die Generierung von Neuem (Mediatization as Meta-Process: Transformation, Forms of Development and the Creation of New Ideas). Medien - Kultur - Kommunikation. Wiesbaden: Springer VS.

$>$ Hepp, Andreas; Berg, Matthias and Roitsch, Cindy (2015) Mediengeneration als Prozess: Die mediengenerationelle Selbstpositionierung älterer Menschen (Media Generation as Process: The Elderly Peoples' Media Generational Self-Optimization). Medien \& Altern 6 (6): 20-33.

$>$ Hepp, Andreas; Berg, Matthias and Roitsch, Cindy (eds) (2014) Mediatisierte Welten der Vergemeinschaftung, Kommunikative Vernetzung und das Gemeinschaftsleben junger Menschen (Mediatized Worlds of Communitization, Communicative Networking and the Community Life of Young People). Wiesbaden: Springer VS.

>Horn, Sebastian S.; Ruggeri, Azzurra and Pachur, Thorsten (2016) The development of adaptive decision making: Recognition-based inference in children and adolescents. Developmental Psychology, 52 (9): 1470-1485. https://doi.org/10.1037/dev0000181.

$>$ Hüther, Jürgen (2005) Erwachsenenbildung und Medienpädagogik (Adult Education and Media Pedagogy), pp. 82-88 in Hüther, Jürgen and Schorb, Bernd (eds) Grundbegriffe Medienpädagogik (Basic Terms Media Pedagogy). München: kopaed.

$>$ Hüther, Jürgen and Podehl, Bernd (2005) Geschichte der Medienpädagogik (History of Media Pedagogy), pp. 116-127 in Hüther, Jürgen and Schorb, Bernd (eds) Grundbegriffe Medienpädagogik (Basic Terms Media Pedagogy). München: kopaed.

>Initiative D21 e.V. (2019) D21-Digital-Index 2018/2019. Initiative D21 e.V. \& Kantar TNS (eds.). https:// initiatived21.de/app/uploads/2019/01/d21_index2018_2019.pdf (02/09/2019).

> Jäger, Georg (1988) Der Kampf gegen Schmutz und Schund. Die Reaktion der Gebildeten auf die Unterhaltungsindustrie (The Fight against Dirt and Trash. The Reaction of the Educated to the Entertainment Industry). Archiv für Geschichte des Buchwesens 31: 163-192.

>JFF (2018) The JFF - Information in English. JFF - Institut für Medienpädagogik in Forschung und Praxis (Institute for Media Pedagogy in Research and Practice). https://www.jff.de/ueber-uns/hinweisenglisch (20/11/2018).

$>$ JuSchG \& JMStV (2015) Jugendschutzgesetz und Jugendmedienschutz-Staatsvertrag der Länder Jugendschutzgesetz und Jugendmedienschutz-Staatsvertrag der Länder (Youth Protection Act and State Treaty on the Protection of Minors in the Media of the Federal States of Germany) https://www.kjm-online.de/fileadmin/user_upload/Rechtsgrundlagen/Gesetze_Staatsvertraege/ JMStV_Genese/Jugendmedienschutz-Staatsvertrag__JMStV__in_der_Fassung_des_19._RA__StV. pdf (12/12/2019).

>KJM (2019) Kriterien für die Aufsicht im Rundfunk und in den Telemedien (Criteria for the Control of Broadcasting and Telemedia). Kommission für Jugendmedienschutz (Commission for Youth-MediaProtection). https://www.kjm-online.de/publikationen/pruefkriterien/ (19/08/2019). 
>Klein, Anika (2017) Der Weg ins digitale Netz - Eine Frage des Alters und der Generation? Ergebnisse einer qualitativen Studie zur Bedeutung von Alters- und Generationsstereotypen für den Umgang mit digitalen Medien (The Way into the Digital Network - A Question of Age and Generation? Findings of a Qualitative Study about the Meaning of Age- and Generational Stereotypes to the Handling with Digital Media), pp.61-77 in Mayrberger, Kerstin; Fromme, Johannes; Grell, Petra and Hug, Theo (eds) Jahrbuch Medienpädagogik 13 (Yearbook Media Pedagogy Vol. 13). Wiesbaden: Springer VS. https://doi.org/10.1007/978-3-658-16432-4_5.

$>$ Kohring, Torben and Heinz, Daniel (2012) Treffen der Generationen. Gamespädagogik als Chance für die Intergenerationenarbeit (Games-pedagogy as chance for intergenerational work), pp. 125136 in Ganguin, Sonja; Meister, Dorothee (eds) Digital native oder digital naiv? Medienpädagogik der Generationen (Digital native or digital naive? Media pedagogy of generations). GMK $>$ Krampen, Günter (2008) Cognitive development in children aged 3 to 8 years: Concentration and the transition from preoperational to concrete-operational cognition. Zeitschrift für Entwicklungspsychologie und Pädagogische Psychologie (40): 79-86. https://doi.org/10.1026/00498637.40.2.79.

>Krekula, Clary; Nikander, Pirjo and Wilińska, Monika (2018) Multiple Marginalizations Based on Age: Gendered Ageism and Beyond, pp. 33-50 in Ayalon, Liat and Tesch-Römer, Clemens (eds) Contemporary Perspectives on Ageism, International Perspectives on Aging. https://doi. org/10.1007/978-3-319-73820-8_3.

>Krotz, Friedrich (2001) Die Mediatisierung kommunikativen Handelns: Der Wandel von Alltag und sozialen Beziehungen, Kultur und Gesellschaft durch die Medien (The Mediatization of Communicative Acting: The Change of Everyday and Social Relationships, Culture and Society Through Media). Wiesbaden: Westdt. Verl.

>Kruse, Andreas (2011) Offenheit, Generativität und Integrität als Entwicklungsaufgaben des hohen Alters (Openness, Generativity and Integrity as Development-Tasks of Higher Age), pp. 243-260 in Kollewe, Carolin and Schenkel, Elmar (eds) Alter: unbekannt. Über die Vielfalt des Älterwerdens. Internationale Perspektiven (Age Unknown: About the Diversity of Aging. International Perspectives). Bielefeld: transcript.

$>$ Kübler, Hans-Dieter (1996) Kompetenz der Kompetenz der Kompetenz. Anmerkungen zur Lieblingsmetapher der Medienpädagogik (Competence of Competence of Competence. Remarks on the Media Pedagogy's Favourite Metaphor). medien praktisch 20 (2): 11-15.

>Kübler, Hans-Dieter (2019) Die Nutzung von Smartphones und Tablets durch Senior/innen (The Usage of Smartphones and Tablets Through Seniors). Medien \& Altern 14 (06).

>Livingstone, Sonja; Papaioannou, Tao; Grandío Pérez, Maria del Mar and Trültzsch-Wijnen, Christine W. (2012) Critical Insights in European Media Literacy Research and Policy. Media Studies 3 (6): 2-12.

>Loos, Eugène (2012) Senior citizens: Digital immigrants in their own country? Observatorio, 6 (1): $1-23$.

>Loos, Eugène and Ivan, Loredana (2018) Visual Ageism in the Media pp. 162-176. in Ayalon, Liat and Tesch-Römer, Clemens (eds) Contemporary Perspectives on Ageism, International Perspectives on Aging. https://doi.org/10.1007/978-3-319-73820-8_1.

>Mayer, Anne-Kathrin (2009) Altersbilder und die Darstellung älterer Menschen in den Medien. Vermittelte Altersbilder und individuelle Altersstereotype (Images of Age and the Portrayal in the Media. Mediated Images of Age and Individual Stereotypes of Age), pp. 114-129 in Schorb, Bernd; Hartung, Anja and Reißmann, Wolfgang (eds) Medien und höheres Lebensalter. Theorie Forschung - Praxis (Media and Higher Age. Theory - Research - Practice). Wiesbaden: VS Verlag für Sozialwissenschaften.

>Moser, Heinz (2010) Einführung in die Medienpädagogik. Aufwachsen im Medienzeitalter (Introduction in the Media Pedagogy. Growing up in a Media Age). Wiesbaden: VS Verlag für Sozialwissenschaften. 
>mpfs (2018) Über den mpfs (About mpfs). Medienpädagogische Forschungsverbund Südwest (Media Pedagogical Research-Association South-West). https://www.mpfs.de/ueber-den-mpfs/ (20/11/2018).

$>$ Oerter, Rolf and Dreher, Eva (2008) Jugendalter (Adolescence), pp. 271-332 in Oerter, Rolf and Montada, Leo (eds) Entwicklungsspychologie [Lehrbuch] (Developmental Psychology [textbook]) (6th Ed.). Weinheim; Basel: BeltzPVU.

>Potter, James W. (2004) The Media Literacy Model. http://www.sagepub.com/sites/default/files/ upm-binaries/4889_Potter_Chapter_3_Media_Literacy_Model.pdf (03.05.2019).

$>$ Prensky, Marc (2001) Digital Natives, Digital Immigrants Part 1. On the Horizon 9 (5): 1-6. https://doi. org/10.1108/10748120110424816.

$>$ Rebelo, Catarina (2018) Ageism in the narratives of older people about ICT's adoption and use. Presentation at European Communication Research and Education Association (ECREA) Conference: Digital Culture and Communication. Lugano, 03/11/2018.

$>$ Rosales, Andrea and Blanche-Tarragó, Daniel (2018) Family dynamics supporting grandmothers to digital literacy, an intercultural analysis. Scientific lecture at the Conference-Panel: Digital Culture and Communication. European Communication Research and Education Association (ECREA). Lugano, 03/11/2018.

$>$ Rosenstock, Roland (2007) Medien im Lebenslauf: Demographischer Wandel und Mediennutzung (Media in Life Course: Demographic Change and Media-Usage). München: kopaed.

$>$ Röser, Jutta (2017) Silversurfer 70plus.Qualitative Fallstudien zur Aneignung des Internets in der Rentenphase (Silversurfer 70plus. Qualitative Case-Study about the Appropriation of Internet in the Phase of Retirement). München: kopaed.

$>$ Rothermund, Klaus and Temming, Felipe (2010) Diskriminierung aufgrund des Alters (Discrimination Because of Age). Antidiskriminierungsstelle des Bundes (Federal Anti-Discrimination Agency). http:// www2.uni-jena.de/svw/allgpsy2/data/rothdata/RT10.pdf (20.11.2018).

>Sanchez-Valle, Maria; Abad-Alcalá, Leopoldo; Pretel-Jiménez, Marile; Viñarás-Abad, Mónica and Llorente-Barroso, Carmen (2018) Challenges for e-administration in contact with elderly. Scientific lecture at the Conference-Panel: Organisational and Strategic Communication. European Communication Research and Education Association (ECREA). Lugano, 03.11.2018. $>$ Schäffer, Burkhard (2003) Generationen - Medien - Bildung: Medienpraxiskulturen im Generationenvergleich (Generations - Media - Education: Media-Practice-Culture in a Gernerational Comparison). Opladen: Leske + Budrich. https://doi.org/10.1007/978-3-322-94996-7.

$>$ Schaller, Klaus (1995) Die Didaktik des Johann Amos Comenius zwischen Unterrichtstechnologie und Bildungstheorie (The Didactic of Johann Amos Comenius between Teaching Technology and Attachment Theory), pp. 47-60 in Hopmann, Stefan and Riquarts, Kurt (eds) Didaktik und/oder Curriculum. Grundprobleme einer international vergleichenden Didaktik (Didactic and/or Curriculum. Basic Problems of an International Comparative Didactic) Weinheim a.o.: Beltz.

>Scherr, Albert (2017) Soziologische Diskriminierungsforschung (Sociological DiscriminationsResearch), pp. 39-58 in Scherr, Albert; el Mafaalani, Aladin and Yüksel, Emine (eds) Handbuch Diskriminierung (Handbook Discrimination). Wiesbaden: VS Verlag für Sozialwissenschaften. https:// doi.org/10.1007/978-3-658-11119-9_3-2.

>Schiefner-Rohs, Mandy (2013) Medienpädagogik. Strömungen, Forschungsfragen und Aufgaben (Media Pedagogy. Tendencies, Research Questions and Tasks), in Ebner, Martin and Schön, Sandra (eds) L3TLehrbuch für Lernen und Lehren mit Technologien (L3TTextbook for Learning and Teaching with Technology) (2nd Ed.). Frankfurt: PeDocs.

>Schorb, Bernd (2017) Medienkompetenz (Media Competence), pp. 254-261 in Schorb, Bernd; Hartung-Griemberg, Anja and Dallmann, Christine (eds) Grundbegriffe Medienpädagogik (Basic Concepts Media Pedagogy) (6th Ed.). München: kopaed. 
>Schorb, Bernd (2009) Erfahren und neugierig - Medienkompetenz und höheres Lebensalter (Experienced and Curious - Media Competence and Higher Age), pp. 319-337 in Schorb, Bernd; Hartung, Anja and Reißmann, Wolfgang (eds) Medien und höheres Lebensalter. TheorieForschung - Praxis (Media and Higher Age. Theory - Research - Practice) Wiesbaden: VS Verlag für Sozialwissenschaften. https://doi.org/10.1007/978-3-531-91900-3_24.

$>$ Schorb, Bernd (2003) Politische Sozialisation durch Medien (Political Socialisation Through Media), pp. 75-92 in Fritz, Karsten; Kersting, Stephan and Vollbrecht, Ralf (eds) Mediensozialisation: Pädagogische Perspektiven des Aufwachsens in Medienwelten (Media-Socialization: Pedagogical Perspectives of Awakening in Media-Worlds) Opladen: Leske + Budrich. https://doi.org/10.1007/978-3322-87371-2_6.

>Schorb, Bernd (1997) Vermittlung von Medienkompetenz als Aufgabe der Medienpädagogik (Mediation of Media Competences as Media Pedagogies' Task), pp. 63-75 in Enquette Kommission, Deutscher Bundestag (German Bundestag's Commission of Inquiry) (ed.) Medienkompetenz im Informationszeitalter. "Zukunft der Medien in Wirtschaft und Gesellschaft; Deutschlands Weg in die Informationsgesellschaft" Vol.4 (Schriftenreihe "Enquete-Kommission: Zukunft der Medien"), Bonn. >Schorb, Bernd (1995) Medienalltag und Handeln: Medienpädagogik im Spiegel von Geschichte, Forschung und Praxis (Media Every Day and Action: Media Pedagogy in the Reflection of History). Opladen: Leske + Budrich. https://doi.org/10.1007/978-3-322-92573-2.

>Settersten, Richard A. Jr. and Mayer, Karl U. (1997) The Measurement of Age, Age Structuring, and the Life Course. Annual Review of Sociology 23 (1): 233-261. https://doi.org/10.1146/annurev. soc.23.1.233.

>Simon, Gertrud, Haring, Solveig, Noack, Horst and Reis-Klingspiegl, Karin (1999) Altern als Herausforderung (Aging as Challenge). Schriftenreihe / Arbeitsgemeinschaft für Sozialforschung und SozialplanungSteiermark (Publication Series / Working Group of Social-Research and Social Planning Steiermark), Vol. 7. Graz: Leykam.

>Sodian, Beate (2008) Entwicklung des Denkens (Development of Thinking), pp. 436-478 in Oerter, Rolf and Montada, Leo (eds) Entwicklungsspychologie [Lehrbuch] (Developemental Psychology [textbook]) (6th Ed.). Weinheim; Basel: Beltz PVU.

$>$ Stöber, Rudolf (2003) Mediengeschichte. Die Evolution "Neuer"Medien von Gutenberg bis Gates. Eine Einführung. Film - Rundfunk - Multimedia (Media History. The Evolution of "New" Media from Gutenberg to Gates. An Introduction. Movie - Broadcasting - Multimedia) Vol. 2. Wiesbaden: Westdeutscher Verlag.

>Stone, Mary Ellen; Lin, Jielu; Dannefer, Dale and Kelley-Moore, Jessica A. (2016) The Continued Eclipse of Heterogeneity in Gerontological Research. The Journals of Gerontology Series B: Psychological Sciences and Social Sciences 72 (1): 162-167. https://doi.org/10.1093/geronb/gbv068. >Süss, Daniel; Lampert, Claudia and Wijnen, Christine W (2013) Ein Blick zurück: Zur Entwicklung der Medienpädagogik im deutschsprachigen Raum (A View Back: To the Development of Media Pedagogy in German-Speaking Area), pp. 61-94 in Süss, Daniel; Lampert, Claudia and Wijnen, Christine W. (eds) Medienpädagogik. Ein Studienbuch zur Einführung (Media Pedagogy. A Textbook for Introduction). Wiesbaden: VS Verlag. https://doi.org/10.1007/978-3-531-19045-7_3.

>Süss, Daniel; Lampert, Claudia and Wijnen, Christine W. (2010) Medienpädagogik (Media Pedagogy). Wiesbaden: VS Verlag. https://doi.org/10.1007/978-3-531-92142-6.

>Swertz, Christian and Fessler, Clemens (2010) Literacy - Facetten eines heterogenen Begriffs (Literacy - Facets of a Heterogeneous Terms). http://homepage.univie.ac.at/christian.swertz/ texte/2010_literacy/2010_literacy.pdf (03/05/2019).

$>$ Thomas, Dorothy S. and Thomas William I. [1928] (1970) Situations defined as real are real in their consequences, pp. 154-155 in Stone, Gregory P. and Farberman, Harvey A. (eds) Social psychology through symbolic interaction. Waltham, MA: Xerox College Publishing.

>Thalhammer, Veronika (2017) Medienkompetenzerwerb intergenerationell (Acquiring media literacy in an intergenerationally way). München: kopaed.

$>$ Tulodziecki, Gerhard (1997) Medienerziehung in Schule und Unterricht (Media Education in School and Class) (3rd Ed.). Bad Heilbrunn: Klinkhardt. 


\section{MEDIJSKA PEDAGOGIJA NEOVISNA O DIIMENZIJI DOBI}

\section{Rebekka Haubold}

SAŽETAK Dob je statična sociodemografska dimenzija, no pitanje je je li to još uvijek korisna kategorija za medijsku pedagogiju i medijske kompetencije. Ovaj članak teorijski propituje usredotočenost na dob u istraživanju i praksi njemačke medijske pedagogije. Teza ovog članka jest da se dominantni fokus na dob treba preusmjeriti na zanemarene kontekste i načine kako ih otkriti. Ključna je stvar razlikovati slučajeve u kojima ima smisla usredotočiti se na dobne skupine u medijskim pedagoškim istraživanjima i praksama od onih u kojima je to diskriminatorno i manje važno od ostalih čimbenika. Stoga se analizira povijesni razvoj koji je opravdao koncentraciju na tu temu u njemačkoj medijskoj pedagogiji i prekomjerni naglasak na pojmovima koji se vezuju uz dob.

KLJUČNE RIJEČI

MEĐUGENERACIJSKI PRISTUP, MEDIJSKA PEDAGOGIJA, NJEMAČKA, DISKRIMINACIJA, PISMENOST

Bilješka o autorici

Rebekka Haubold :: Leipzig University, Leipzig, Njemačka :: rebekka.haubold@uni-leipzig.de 